執するからだと説明している。（Safranek らはエレクト ログラフ印刷法を巧みて利用して，クロムメッキのクラ ック，多孔性の問題を究明している。）

第 3 表は HTHR 浴に関する実験結果を表示したもの で, 特に多孔性の割れやすさの欄に注目すべきである。 一方 Metal \& Thermit 社からは, CF-520 浴々称す る光沢クラックフリークロム浴が市販されている。 これは $\mathrm{SO}_{4}=$ と $\mathrm{Si} \mathrm{F}_{6}=$ を含を一種の SRHS 浴で, $\mathrm{CrO}_{3} 370 \mathrm{~g} / l$, 温度 $50^{\circ} \mathrm{C}$ で操作されるものである。

前述の HTHR 浴は主として亚鉛ダイカスト部品を刘 象に研究されたるので，本質的にはサージェント浴の変 則的使用であるから，操作範囲に制限があることは避け られない。しかし，この CF-520浴は，元来性能の良 いケイフッ化浴を, 特にクラックフリークロム用に改良 したものであるから，操作は比較的容易である。

二重クロムメッキとは，この上にさらに CR-110浴と 呼ばれる中濃度 SRHS浴 $\left(\mathrm{C}_{2} \mathrm{O}_{3} 250 \mathrm{~g} / l\right)$ から重ねてメ ッキする方法で, 上層は独特の微小クラックを有し, 合 計 $2.5 \sim 5 \mu$ 程度にメッキすると, クラックフリークロ ムだけの場合よりも耐食性はさらに一段と改良されると い5。

二重クロムメッキによる耐食性向上の理論的根拠は十 分明らかにされていないが，最外層のクロムメッキの有 する割レ状態 (crack pattern) によって全体の耐食性が 影響されることも考えられる。

たとえば，Safranek ${ }^{11)}$ らは普通浴に巫セレン酸を添 加することによって，クロムメッキ層に微小クラックを 生じ, $1 \sim 2 \mu$ メッキすると, 亚セレン酸を含まない浴か らクロムメッキした場合よりすぐれた耐食性を示すと報 じている。すなわち下記の組成条件のものである。

$\begin{array}{ll}\mathrm{CrO}_{3} & 250 \mathrm{~g} / l \\ \mathrm{H}_{2} \mathrm{SO}_{4} & 2.5 " \prime \\ \mathrm{SeO}_{2} & 0.007 " \\ \text { 温度 } & 43 \sim 45^{\circ} \mathrm{C}\end{array}$

この他に契用上の問題は别として, $\mathrm{Cu}-\mathrm{Cr}-\mathrm{Ni}-\mathrm{Cr}$, $\mathrm{Ni}-\mathrm{Cr}-\mathrm{Ni}-\mathrm{Cr}$ などの方式が研究されている。

いずれにしても, 装飾クロムメッキに拈けるクロムメ ッキの地位は, 少なくとも話題の上では 180 度転換を遂 げたわけで，今後の成り行きが注目される。

\section{6. 結言}

以上述べたような装飾クロムメッキの耐食性問題に関 する動きは，将来まだまだ動摇を続けそらである。これ までの動向を限られた紙数で適確に描写できたかぞう か，筆者自身疑問飞思うが，この方面にいままであまり 関心を持たなかった方々にいくぶんの参考となれば幸い である。

\section{交献}

(1) Frank, Plating, 47, 623 (1960)

(2) Safranek, Miller, Faust Proc. AES, 46, 133

(3) Nixon, Thomas, Hardesty Proc. AES 46, 159 (1959)

(4) Pinner, Plating, 44, 763 (1957)

(5) Bigge, Proc. AES, 46, 149 (1959)

(6) Edwards, Proc. AES, 46, 154 (1959)

(7) Bigge, Plating, 47, 1263 (1960)

(8) Safranek, Metal Progress, Jul., 71 (1960)

(9) Baker \& Pinner, SAE Jounal, 22, 331 (1928)

(10) Safranek, Plating, 47, 513 (1960)

(11) Safranek, Plating, 47, 1027 (1960)

\title{
電気的, 化学的加工法の進歩
}

東京大学工学部 工博 倉藤 尚雄

\section{1. はしがき}

電気と薬品を使って行なう表面処理法は, 会員の皆さ んのよく知っておられることであるが，近年非常に進步 をした。その成果は表面処理,つまり表面に耐食,耐摩耗 性を持たせ，美観をあたえることばかりでなく，一歩進 んで, この方法で品物の形状寸法までもコントロールす る，いわゆる成形にまで使われるようになった。その結 果, 電気, 金属, 機械方面からる研究に参加する人々が ふえ, 工場内でもメッキ場ばかりでなく, 工作機械の一
つとして機械工場に並べて使われるものまで出てきた。 今回はこれらについてご紹介する。

\section{2. 分 類}

電気と化学を利朋する加工法は大別すると，第 1 表の ように化学的作用を主とするもの, 電気的作用を主とす るもの，兩作用を併用するものの三つになる。

\section{3. 腐食 加工}

これは,メダル，銘板の製作法の改良で，第 2 表のよ 
第 1 表 電気的，化学的加工法の分類

\begin{tabular}{|c|c|}
\hline $\begin{array}{l}\text { 学 加工 法 } \\
\text { Chemical } \\
\text { Machining) }\end{array}$ & $\begin{array}{l}\text { 腐食加工(Chemical Milling) } \\
\text { 析出加工(Chemical Depositing) }\end{array}$ \\
\hline $\begin{array}{l}\text { 気化学加工 } \\
\text { lectro-Chemical } \\
\text { Machining) }\end{array}$ & $\left\{\begin{array}{l}\text { 電解加工(Electro-Grinding, } \\
\text { Electro-Diesinking } \\
\text { 電着加工(Electroforming) }\end{array}\right.$ \\
\hline $\begin{array}{l}\text { 気 加 工 } \\
\text { Machining) }\end{array}$ & $\begin{array}{c}\text { 放電加工(Electrical Discharge } \\
\text { Machining) } \\
\text { 電子ビーム加工 (Electron-Beam } \\
\text { Machining) } \\
\text { プラズマジェット加工 } \\
\text { (Plasma-Jet Machining) }\end{array}$ \\
\hline
\end{tabular}

ろな利点があるため, 航空機, 自動車工業, 目盛, バネ などに広く用いられ始めた。

腐食させたくない部分は，ネオプレン，ビニル，ワッ クス，銀膜などでお括い，腐食液につける。膜をつける には品物全体を液につけ，または吹付けて固化させ，輪 郭を切って腐食部をはぎ取ることもあれば，型板をあて て吹付けることもある。また写真腐食法を用いることも ある。液は一般に塩化第二鉄水溶液を用いるが， $\mathrm{A} l$ に はカセイソーダ, ガラスにはフッ化水素を用いる。

精度は一般には高くないが，目盛線のように浅い場合 には, 長サ $75 \mathrm{~mm}$ につき $\pm 5 \mu$, 角度は $\pm 30 \mathrm{~s}$, 線の幅 は $0.25 \mathrm{~mm}$ に対して $\pm 0.03 \mathrm{~mm}$ くらいの䛊差ででき る。深くなると，第 1 図に示すように食込ミが起こるの で, 幅, 深サ共に誤差を生じる。深サの䛊差は $1 \mathrm{~mm} て ゙$ $\pm 0.05 \mathrm{~mm}, 3 \mathrm{~mm}$ では $\pm 0.08 \mathrm{~mm}$ くらいある。

現在は $\mathrm{Al}, \mathrm{Cu}, \mathrm{Ni}, \mathrm{Fe}, \mathrm{Co} と ゙$ 金属, 合金に用いら れている。この他超硬合金チップをバイトの柄にロウ付 ケするとき, 腐食加工で平面研摩すると安価で有効だと の報告もある。

\section{4. 析 出 加 工}

化学メッキによって，希望の部分に金属を析出させる とわずかに寸法,形状を変更できる・まだあまり使われて いないが,反射鏡の曲率を变えるのに使った例*がある。

\section{5. 電解 研 削 加 工}

品物を陽極として電解すると, 溶け出して寸法, 形状 が变わる。つまり電解研摩を強力に実施すると, 成形が できる。これを電解加工と言っている。電解研摩とのち

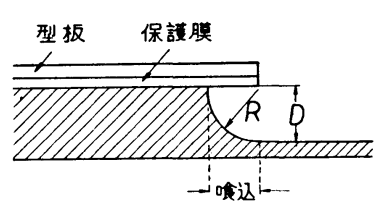

第 1 図 がいは溶け方が著しく 早く, 形状, 寸法が正 確にできることであ る。

* 静大工学部 木義一氏
第 2 表 磨食加工法の特徵

a . 化学的に溶解するので, かたい材料です容易で, 加 エによるヒズミ, バリを生じないし, 加工のためそ硬 化することもない。

b . 文字, 模様などの彫刻, 材料の肉抜き, テ一パ付ヶ ができる。

c ・曲面に加工することは従来むずかしかったが，本法 では平面と同様に容易である。

d・タンクだけあればよいので, 設備は安価ですむ。

e . 広い面積あるいは多数個を同時に加工できるので,

大物または多量生産のときは, 従来の方法より時間が 短くてすむ，熟練工はいらない。

f . 面は清浄であるから，すぐ表面処理ができる。

この差の原因は, 電解研摩のとき, とけ出して液と作 用してできる陽極生成物の膜を取り除いたためである。 この生成物は母液に比し, 電気抵抗が著しく高いので電 流の通過を妨げる。これを拭さとるあるいは流しとる と, 大電流が流せるので, 容易に数10～数 100 倍の溶解 速度が得られる。拭き方によって方法が分かれる。

\section{5-1 䧎極法}

陰極で品物（陽極）表面を軽くなで，陽極膜を拭きと る。このときは両極が直接接触しないように,比較的粘る 電解液を使 5 。水ガラス水溶液（d 1.3〜 1.4）を使 5 ことが多い。（第 2 図 a 参照）超硬合金付临のフライス, 錐などを研摩するには，円板状電極を用い,周速 $20 \mathrm{~m} / \mathrm{s}$, DC 電圧 $24 \mathrm{~V}$, 80A で粗加工, $30 \mathrm{~A}$ で仕上加工を行ない, $0.8 \sim 1.6 \mu \mathrm{hms}$ くらいの面が得られる。

\section{5-2 中性極法}

陰極 $\mathrm{E}$ と絶縁した金属，または絶縁物（ガラス，ト イシなど）つまり中性極Nで陽極膜をらき取るやり方で ある。トイシとしては粗加工に No. 80〜120 のアランダ ムトイシ，仕上ゲはNo. 400 のカーボランダムトイシを 使 5 。

（第 2 図 $\mathrm{b}$ 参照）

超硬合金工具を研摩するとき，あるいは孔の内面のホ ーン仕上ゲのときは円板電極の周速 $29 \mathrm{~m} / \mathrm{s}$, 電圧 DC $24 \mathrm{~V}$, 3〜10A くらいで加工し， $0.1 〜 0.8 \mu \mathrm{rms}$ の面が得られ

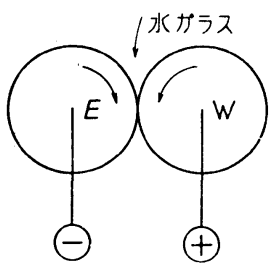

a

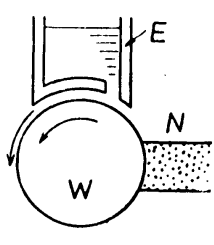

b
第 2 図 
る。このときの加工速度はトイシ加工と同じくらいであ るが，仕上ガリが著しくすぐれ，トイシはほとんど消耗 しない。

\section{5-3 複合画極法}

金属ボンドのダイヤモンドトイシを用い，これで品物 を軽く摩擦すると,同じ効果がある。極間距離はダイヤモ ンドの突出した高サしかないので, 大電流が流れて早く 加工ができ, 電流はその部だけに集中するので, 他の面 を腐食することが少ない。（第2 図c参照）

あまり強く押し付けなければトイシの消耗はほとんど ないので,ダイヤモンドトイシの必要はなく,アランダム, カーボランダム, ルビー, 石英, ガラスでもよい。ただ し, 突出部は摩擦作用を受けるので, 耐摩耗性の大さい ダイヤモンドが, 寿命の点から使われているのである。

こういう点から, 普通のダイヤモンドトイシはもった いないので，単層トイシが作られ始めた。その方法は第 3図のよ5に金属リング( $\mathrm{a}$ )にうすく接着材を鉒り(b) ダイヤモンド粉をまき（c）硬化させる。厚くニッケル メッキし（d）表面を平に研摩し，これを金属円板に口 ウ付ヶし（e）リングをはがし取る。こうすると, 地金 (ニッケル) からのダイヤモンドの突出量が一定になっ て好ましい。もら一つの方法は, 成形した銅円板上にう すくダイヤモンド粉をまき，ロールで押し付ける。こう すると精密な電極（䛊差士 2 3 3 ） が容易にできる。こ の上にうすくニッケルメッキすると，むちがよくなる。

電解液はいろいろなものが使えるが，超硬質合金には 硝酸ナトリウム $5 \%$ 液を用いる。

接触圧は実験によると, 大さいほど加工速度（溶解速 度)が早くなるが，押付けすぎると,摩擦でト粒の脱落が はげしくなってトイシが消耗する。また極間が接近しす ぎて放電し，研削面があれるとともに，トイシもいたむの で,陽極膜をかき取るだけにとめる。これは 3〜 $4 \mathrm{~kg} / \mathrm{cm}^{2}$ くらいである。

電極と品物の接触面積 (㛜密には対向面積) は同時に 加工されるから，広い方が有利である。そこでなるべく 全面同時に加工または多数同時に行な弓。電極の回転速 度も院極法, 中性極法と同じであるが, 液の飛散からは おそい方が好ましい。電流密度に比例して加工速度はま

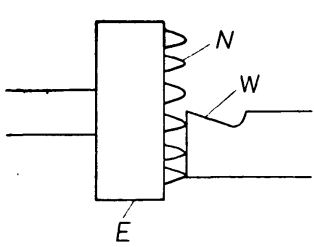

C

第 2 図

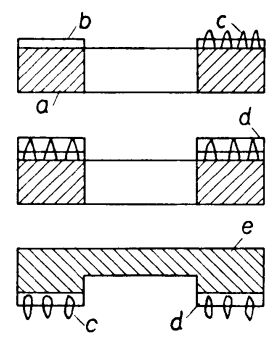

第 3 図
第 3 表 超硬合金研削法の比較（米）

\begin{tabular}{l|c|c}
\multicolumn{1}{c|}{ 研 削 法 } & $\begin{array}{c}\text { 加工速度 } \\
\mathrm{mm}^{3} / \mathrm{min}\end{array}$ & $\begin{array}{c}\text { 仕_I:粗さ } \\
\mu \text {-in-rms }\end{array}$ \\
\hline 電解研削 (平面) & 556 & $10 \sim 12$ \\
G C 研削 (重) & 262 & 140 \\
電解研削 (手トギ) & 248 & $8 \sim 12$ \\
G C 研削 (粗) & 163 & 50 \\
放電研削 (粗) & 131 & 50 \\
D研削 (手,レシンボンド) & 65 & 9 \\
放電研削 (仕上ゲ) & 5 & $10 \sim 12$ \\
\hline
\end{tabular}

すが，飽和するので，限度がある。

他の研削法との比較は第 3 表のようになかなかすぐれ ている。現在超硬合金を早く加工するには, G Cトイシに よるのが一番で, よい仕上ゲはDトイシ(ダイヤモンド) を使うのが普通である。これに比べて電解研削 (平面) は加工速度がG C の 2 倍で, 仕上ゲは研削とほぼ同じで ある。いかに有効かが判る。また別の報告では, 数 $10 \mathrm{~A}$ 以上ではコストもD㸴削より安いといらことである。

\section{5-4 電解研削の応用と裝置}

この方法中, ソ連では陰極法，中性極法が用いられて いて, 超硬合金工具, 特殊鋼の研摩, 孔のホーニングが 行なわれている。専門機はまだなく, 改造機らしい。従 来のバイト研摩盤, 平面研摩船, 円筒研摩盤はもちろん 形削盤, 平削盘までも容易に電解研削用に改造でき, ま たしている。

米国では主としてバイト研削に使われ, フライス, タ 一ビン翼, カム, ハニカム, 注射針の刚先の研摩にも使 用されつつある。ハニカムというのは厚サが 0.02〜0.1 $\mathrm{mm}$ の板を蜂巣状に組み合わせた構造材で，これに表皮 を貼りつけると重量に比し強度が著しく強いので, 飛行 機材，エレベータ部分などに使われる。これを削るとき 力をかけるとつぶれるので, 力のかからない電解研削は 最適である。皮下注射針は 18-8 ステンレス鋼のパイプ から作るが,軟いので先端をとぐときに,5すい, ひらひ らした部分が残る。注射のときこれが曲って「カギ」状 になるため大変痛い。電解研削では生じないので好都合 である。

\section{6. 電解型彫リ加工}

パイプ状電極から液を吹出しながら電解する(第 4 図) と, 電極に相当した四みを生じるから, 電極と進める

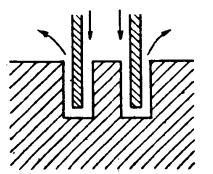

第 4 図 （送る）と孔になり，遂には突き抜 ける。これを利用すると折れ込んだ キリ,タップなどの除去もできる。ま た製品と同じ形の電極から液を吹き 出して行ならと, その品物の鍛造 型, ダイカスト型などができる。 
この時電極材料はへらないので, $\mathrm{Sn}, \mathrm{Pb}$ ，ハンダのよ らなもので簡単に作ってもよい。電解液もいろいろなる のが使えるが，たと兊ば鋼に対しては食塩水を使っても よい。電流はDC 6 8V で 500〜 50,000 A を使用し, 非常に早く加工ができる。もちろん大電流を使うには, 対向面積が広くなくてはならないが,たと党ば $6,000 \mathrm{~cm}^{2}$ で 50,000 A 使用すると，鋼を $640 \mathrm{~g} / \mathrm{min}$ の速サで加工 できるという。

写真 1 は電解によるタービン翼の成形である。電解型 彫の加工精度は0.08mm, 仕上ゲは 30〜 40 $\mu$-in rmsで, あけられる最小孔は $1 \mathrm{~mm} \phi$ くらいである。

この他, 写真 2 のよに腾写版に似た方式の電解彫刻 装置もある。

\section{7. 放 電 加 工}

スイッチを開くときに火花が出るこれは一種の放電 で，そのためにスイッチがいたむ。これを逆用して加工 に使うようにしたものが放電加工である。この特徵も化 学加工や電解加工とょく似ていて, 従来の加工ではむず かしい，かたい材料の加工に広く用いられている。前の 二つの加工法に比べると, 加工精度が高いのがすぐれた 点で, 広い面積では劣る。

この方法では, 孔アケ, 型崌リ, 切断, 研摩と普通の 工作機械と同じような作業なら何でもでき，刘物，トイ シの代わりに放電が仕事をする。いろいろな電気回路が あるが，簡単なるのは第 5 図のような配線を用いる。

放電加工では, 普通加工の工具飞相当する加工電極 は，加工しょうとする形と反対の形をした黄銅，銅製の

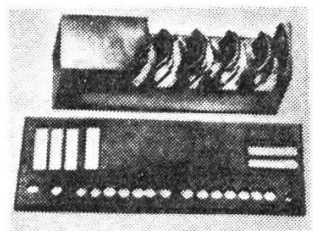
タービン翼(占) と孔, スリット
写真 1 電解による

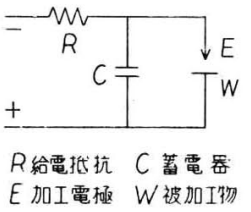

第 5 図
ものを使用する。また放電は空中より液中の方が能率が 高いので灯油の中で行なろことが多い。第4表は第5図の 回路を用いるときの条件の例であるが，もっと高速のと きは数1,000 $\mu \mathrm{F}$ を,むっとよい仕上ゲのときは $0.001 \mu \mathrm{F}$ くらいの蓄電器を使用することも山る。この方法は孔了 ケ，バイト研摩などに使われる。

また丸ノコ，帯ノコ艋で歯のない鋼板をノコギリの代 わりに用い, これを直流電源の負側に, 被加工物を正側 につなぎ，両者を軽く押付けながら，その間に水ガラス

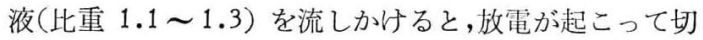
断が行なわれる。このときは電压20～40 V, 電流 1 ～500 Aくらいが用いられ,大電流のときは非常に早く切れる。 また切断代がノユギリより小さいこと，かたい物が切れ

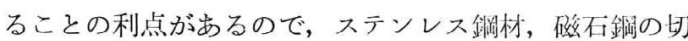
断によく使われている。

また数\%の硝酸ナトリウム，カセイソーダ液の中で, 白金電極に対向させて放電を行ならと，ダイヤモンド， ルビー, ガラスのように電導性のないものでも放電加工 できる。これはダイヤモンドダイス（数 $\mu$ 数 $10 \mu$ の） の加工に広く用いられている。

加工ではないが，空中放電を利用して鋼の表面に超硬 合金, クロム，Cなどをしみ込ませ，硬化，耐耗化， 耐食化する放電硬化法とい5処理法もある。これは第 6 図のようならなぎ方で, 電気アンマの振動器Mを用いれ ば簡単に自製できる。広い面積には不適当だが, 局部硬

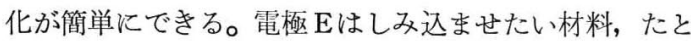
えば超硬合金である。紡織部品,バイトメ先などに試みて 有効である。

さらに炭酸ナトリウム $(10 \%)$ のような電解 液中（第7 図）で200V くらいの電圧をかけると液と被加工間に放 電が起こり, 角の部分から赤くなって行く。希望の部分 まで赤熱されたら，電気を切ると，まわりの液で泠却さ れ焼キが入る。この方法は電解液中放電㹸入レ, 略して 電解焼入レと言われるが, 装置が簡単で, 部分燃入レが でき，効果は高周波烧入レと同じなので，将来広く用い られょう。

第 4 表 放 電 加 工条 件

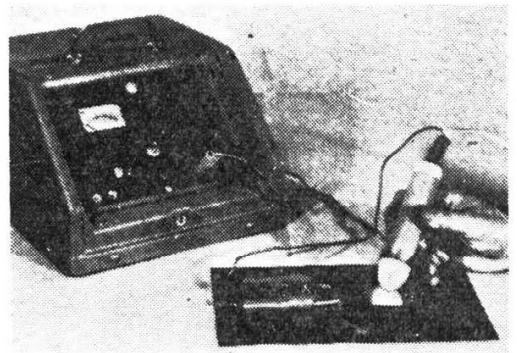

写真 2 電解彫刻装置

\begin{tabular}{|c|c|c|c|c|c|}
\hline 加工、分 & $\begin{array}{c}\text { 蓄電器容量 } \\
\mathrm{C} \mu \mathrm{F}\end{array}$ & $\begin{array}{l}\text { 給電抵执 } \\
\mathrm{R} \Omega\end{array}$ & $\left|\begin{array}{c}\text { 平均電流 } \\
\mathrm{A}\end{array}\right|$ & $\left|\begin{array}{c}\text { J力口速度 } \\
\mathrm{g} / \mathrm{min}\end{array}\right|$ & $\begin{array}{l}\text { 加工面アラ } \\
\text { サ } \mu . \mathrm{rms}\end{array}$ \\
\hline 粗 & $\begin{array}{l}515 \\
270\end{array}$ & $\begin{array}{l}4.1 \\
4.4\end{array}$ & $\begin{array}{l}32 \\
30\end{array}$ & $\begin{array}{l}2.8 \sim 3.8 \\
1.1 \sim 2.9\end{array}$ & $25 \sim 50$ \\
\hline 中 & $\begin{array}{r}120 \\
90 \\
30\end{array}$ & $\begin{array}{l}8 \cdot 3 \\
11 \\
83\end{array}$ & $\begin{array}{c}16 \\
12 \\
1.6\end{array}$ & $\begin{array}{l}0.4 \sim 0.9 \\
0.24 \sim 0.29 \\
0.05 \sim 0.1\end{array}$ & $\begin{array}{l}12.5 \sim 25 \\
6.3 \sim 12.5 \\
3.2 \sim 6.3\end{array}$ \\
\hline 仕上 & 5 & 220 & 0.6 & $60.01 \sim 0.03$ & $1.6 \sim 3.2$ \\
\hline
\end{tabular}

注 電源電压 $220 \mathrm{~V}$ 


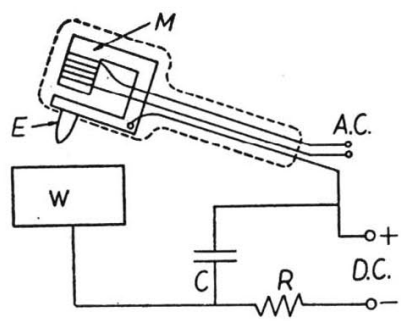

第 6 図

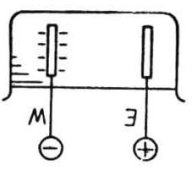

第 7 図

\section{8. 電子ビーム加エ}

電子顕微鏡によく似た装置で，電子のビームを集中し て被加工部にあて, 蒸発させて加工する方法で, 温度が 高いため金属, 非金属共に可能である。この方法は電楆 がいらず, 突抜の小孔によく, 薄い板ならば直径 $1 \mu$ の 孔もできるという。また溶融などにも使われる。

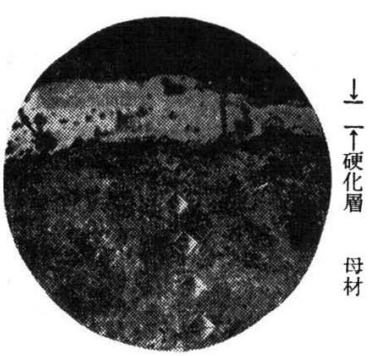

写真 3 放電硬化層の断面
9. プラズマジェッ 卜加工

イオン化したガス流 をノズルから吹出し, 熱によって加工するむ ので, ガス切断に似て いるが, 温度が高いの で，耐熱材料も加工で きる。

\section{交献}

(1) Ken Clark, How to do chemical milling, Am. Machinist, Mar. 24 (1958)

(2) 佐藤敏一; 化学的加工法, 名工部報告, 7-12(昭33) 以降

(3) Now an electrolytic die-sinkor, Metwork Prod., Feb. 19 (1960)

(4) Lynn A Williams, Electrolytic grinding tames hard metals. The Tool Engr, Aug. (1957)

(5) 凰誠三郎, 倉藤尚雄, 放電加工（コロナ社）改訂版

抄

\section{シアン化銅浴中のクロムとその除去法}

E. Laue. AES Technical Proceedings, 188 (1959)

最近では, 同一の引掛ケ治具によって銅一ニッケルー クロムメッキが行なわれることが多い。これによってク ロム酸イオンがシアン化銅浴中に混入する率が多くなっ たが, 従来シアン化銅浴中のクロム酸イオンを除去する ための適当な方法がなかった。

古くから知られている方法は, 次亜硫酸ナトリウムの 添加によって $\mathrm{Cr}^{+6}$ を $\mathrm{Cr}^{+3}$ 飞還元すうもので, 浴中に 酒石酸塩のような二次的錯塩形成剂を含まないときには $\mathrm{Cr}^{+3}$ は水酸化クロムとして沈殿し, 口別することがで きるが，錯塩形成剤の存在の下では， $\mathrm{Cr}^{+3}$ はこれらと 安定な錯塩を形成してて浴中に残り, 再酸化される可能性 がある。

筆者の研究した方法は, 還元剤とクロム媒染々料を浴 中飞添加して不溶性のクロムレーキを沈殿させ，これを 活性炭処理して除去する方法である。すなわち，まず次 业硫酸塩または第一スズ塩を添加して $\mathrm{Cr}^{+6} \rightarrow \mathrm{Cr}^{+3}$ の反 応を完了させ, 次飞アリザリン溶液 $(0.3 \mathrm{M} \mathrm{KOH}$ 溶液 飞 $0.15 \mathrm{M}$ のアリザリンを溶解する。)を添加するか, あ るいは雨者をあらかじめ混合したものを同時に添加して 70 - $80^{\circ} \mathrm{C}$ の下にカクハンを行ない,沈殿を生成させたの ち活性炭処理を行なう。

この反心は酒石酸塩のような錯塩形成剂の存在の下て も可能であるが，これらを含まない場合よりも余分の薬 品と時間を必要とする。 $0.2 \mathrm{~m} \mathrm{~mol} / l$ の $\mathrm{CrO}_{4}=$ を含む場 合飞は $1 \%$ vol. の還元凨溶液 ( $1 \mathrm{~m} \mathrm{~mol} / l$ 水溶液) を加 光, 前記のアリザリン溶液を通常は $1.5 \%$ vol. 錯塩形
成剂の存在するときには 3-6\% vol. の割合で加光る。 過剩のアリザリンは活性炭処理によって完全に除去す ることができる。(中村 実)

\section{Cr-Ni-Cr メッキの耐食性}

H.Brown \& M.Weinberg, AES Technical Proceedings, 128 (1959)

鉄鋼あるいは亜鉛ダイカスト上の装飾クロムメッキの 耐食性を向上するための手段として, $\mathrm{Cu}-\mathrm{Cr}-\mathrm{Ni}-\mathrm{Cr}$ ま たは $\mathrm{Ni}-\mathrm{Cr}-\mathrm{Ni}-\mathrm{Cr}$ などの方式を適用して屋外暴露試験 を行ない, 好結果を得た。

この場合の防食機構は, メッキ表面に生じたピットが ニッケル層を幊通して 2 番目のクロム層に達したとき, .上下のクロム層に対して中間のニッケル層は局部電池の 陽極として活動し，この結果ピットは横方向に成長する のみで、これによって素地のサビの発生が㧕制されるる のと考光られる。

亜鉛ダイカスト部品にこの種の方式を適用する場合に は, 当然 $\mathrm{Cu}-\mathrm{Cr}-\mathrm{Ni}-\mathrm{Cr}$ の組合せが適切である。 $\mathrm{Cu}$ 上 のクロムメッキには, なるべくクラックのない比較的厚 いクロム層が適している。またこのクロム層には特に光 沢を必要としないから, 高温高比率浴 (High Temperature High Ratio Bath) を採用し, 厚サは 0.75-2 $\mu$ と する。クロムメッキ完了の後に, 水洗をよく行なってア ルカリ性還元溶液中に浸セキし, 残留クロム酸を還元す る。

再び水洗ののち, 次の組成のニッケルストライク浴で $2 \sim 6 \mathrm{~A} / \mathrm{dm}^{2}$ Kて 3〜10 min 間ストライクメッキを行な
$5 \circ$
$\mathrm{NiSO}_{4} 6 \mathrm{H}_{2} \mathrm{O}$
$\mathrm{NiCl}_{2} 6 \mathrm{H}_{2} \mathrm{O}$
$\mathrm{H}_{3} \mathrm{BO}_{3}$
$\mathrm{HCl}$
$100 \mathrm{~g} / \mathrm{l}$
$100 \mathrm{~g} / \mathrm{l}$
$30 \mathrm{~g} / \mathrm{l}$ 5 10\% vol.

この種の低 $\mathrm{pH}$ ニッケル浴はクロム酸イオンの混入に 対してかなり鈍感で, 得られるニッケルメッキは密着性 